\title{
The Boundary Between the Not-For-Profit and Business Sectors: Social Enterprise and Hybrid Models
}

\author{
Benjamin Leff \\ Washington College of Law, bleff@wcl.american.edu
}

Follow this and additional works at: https://digitalcommons.wcl.american.edu/facsch_bk_contributions

Part of the Law Commons

\section{Recommended Citation}

Leff, Benjamin, "The Boundary Between the Not-For-Profit and Business Sectors: Social Enterprise and Hybrid Models" (2018). Contributions to Books. 164.

https://digitalcommons.wcl.american.edu/facsch_bk_contributions/164

This Book Chapter is brought to you for free and open access by the Scholarship \& Research at Digital Commons @ American University Washington College of Law. It has been accepted for inclusion in Contributions to Books by an authorized administrator of Digital Commons @ American University Washington College of Law. For more information, please contact kclay@wcl.american.edu. 


\section{Research Handbook on Not-For-Profit Law}

Edited by

Matthew Harding

Melbourne Law School, University of Melbourne, Australia

\section{ED Eublishard Elgar}

Cheltenham, UK - Northampton, MA, USA 
(C) Matthew Harding 2018

All rights reserved. No part of this publication may be reproduced, stored in a retrieval system or transmitted in any form or by any means, electronic, mechanical or photocopying, recording, or otherwise without the prior permission of the publisher.

Published by.

Edward Elgar Publishing Limited

The Lypiatts

15 Lansdown Road

Cheltenham

Glos GL50 2JA

UK

Edward Elgar Publishing, Inc.

William Pratt House

9 Dewey Court

Northampton

Massachusetts 01060

USA

A catalogue record for this book

is available from the British Library

Library of Congress Control Number: 2018946019

This book is available electronically in the Elgaronline

Law subject collection

DOI $10.4337 / 9781785369995$

Printed on elemental chlorine free (ECF)

recycled paper containing 30\% Post-Consumer Waste

ISBN 9781785369988 (cased)

ISBN 9781785369995 (eBook)

Typeset by Columns Design XML Ltd, Reading

Printed and bound in the USA 


\title{
7. The boundary between the not-for-profit and business sectors: social enterprise and hybrid models
}

\author{
Benjamin $M$ Leff
}

\section{INTRODUCTION}

It is conventional to think of not-for-profit organizations as inhabiting a sector distinct from the private business sector on one side and the government sector on the other: ${ }^{1}$ This third sector goes by various names but it generally consists of nonprofit organizations, most of which are devoted to some social or charitable purpose. ${ }^{2}$ The nonprofit sector is generally distinguished from the business sector (i) by the fact that it does not pursue its objectives for the purpose of enriching its participants and (ii) by the fact that it is generally limited to certain activities, which are directed at improving society, sometimes called 'social' goals. ${ }^{3}$ But the boundary between the nonprofit and business sectors has always been indistinct and subject to contestation, ${ }^{4}$ and over the course of the past several decades, this boundary has become more blurred. Many of the ways in which the boundary between the nonprofit and business sectors has become blurred are due to changes in culture, business practices, and institutional norms. But there has also been a movement to change the laws that apply to the nonprofit sector, either through legislation or, more often, through nonprofits innovating to push the boundaries of existing law. While these legal changes are occurring in many jurisdictions around the world, the focus of this chapter is the United States.

One of the traditional goals of law in the nonprofit sector has been to distinguish entities in the nonprofit sector from those in the business sector - to define and police

1 See generally Burton A Weisbrod, The Nonprofit Economy (Harvard University Press 1988) 41.

2 Brice S McKeever, Nathan E Dietz and Saunji D Fyffe, The Nonprofit Almanac (9th edn, Urban Institute Press 2016) 2 ('[the nonprofit sector] is also referred to as the charitable, voluntary, tax exempt, independent, third, social, or philanthropic sector".)

3 Another way of thinking about the primary distinction between the nonprofit and business sectors is that 'the for-profit organization has owners who hold the equity in the enterprise, such as stockholders of a corporation. The for-profit organization is operated for the benefit of its owners'. Nonprofits, by contrast, do not have owners, and are generally operated for some purpose, and any excess value (profits) they accrue is used for that purpose: Bruce $R$ Hopkins, The Law of Tax Exempt Organizations (11th edn, Wiley 2016) 28 (\$1.1).

4 This state of affairs is nicely described in Miranda Stewart, 'The Boundaries of Charity and Tax' in Matthew Harding, Ann O'Connell and Miranda Stewart (eds), Not-for-Profit Law: Theoretical and Comparative Perspectives (Cambridge University Press 2014) 232 ("the tax law of charities thereby constitutes (together with other laws and norms) the boundaries of the state, charity and the market in a "jumbled mixed economy" that changes over time"). 
the boundary. That boundary is defined by law for a number of reasons, the most obvious of which is that the government provides benefits to enterprises that are in the nonprofit sector that it withholds from enterprises in the business sector. The reason tax scholars study nonprofits is that one of the most salient of those benefits in most jurisdictions is some kind of preferential tax treatment, such as exemption from corporate income taxes and a tax subsidy for donations. ${ }^{5}$ But tax benefits are only one of the distinguishing characteristics of the nonprofit sector, and numerous other governmental benefits exist. Whenever the government provides special benefits, legal distinction must be made between the organizations that qualify for those benefits, and the organizations that do not.

The possibility of receiving favourable treatment is not the only reason that a legal boundary between nonprofits and businesses might be justified. The second reason is to enable nonprofits to communicate to stakeholders that the organizations are worthy of support. This rationale - what we might call the 'branding' function of nonprofit law might support a quite different regulatory regime than the one required to distinguish between entities worthy of specific governmental benefits and those that are not. This 'branding' function is essential to the leading economic theory of the nonprofit form, which posits that firms adopt the nonprofit form as a sort of off-the-shelf contract between patrons and a firm, when the firm provides goods or services the quality of which is hard for patrons to evaluate. ${ }^{6}$ Under this theory, by using the "non-distribution constraint' to solve 'contract failure' (or reduce agency costs) the nonprofit firm is able to provide certain goods or services to patrons in the most economically efficient manner.

The nonprofit form is only the most economically efficient arrangement, however, if it is relatively easy for patrons to understand the basic contours of the non-distribution constraint and, most importantly, to identify which firms are subject to it. In other words, the boundary between the nonprofit sector and the business sector must be clearly drawn. Even without expressly accepting this economic argument, many observers of the nonprofit sector believe that its existence depends on a level of trust among stakeholders that requires clear differentiation from the ordinary business sector, and that this ability of stakeholders to trust nonprofit enterprises more than they trust pure business enterprises creates substantial value. ${ }^{7}$ Whatever the rationale, laws are used to create and police the boundary between the nonprofit sector and the business sector. Therefore, when there are legal reforms that complicate or alter the boundary, these reforms should be evaluated not only with respect to whether they adequately

5 See generally Hopkins (n 3) $77 \$ 3.4$.

6 See Henry B Hansmann, 'The Role of Nonprofit Enterprise' (1980) 89 Yale Law Journal 835; Henry B Hansmann, 'Reforming Nonprofit Corporation Law' (1981) 129 University of Pennsylvania Law Review 497.

7 Dennis R Young and Lester M Salamon, "Commercialization, Social Ventures, and For-Profit Competition' in Lester M Salamon (ed), The State of Nonprofit America (Brookings Institution Press 2002) 424 ("nonprofits have accommodated themselves quite well to the commercial pressures they are confronting ... At the same time, it is far from clear whether public understanding, or approval, has kept pace with the scope of the changes under way, with the result that the sector's most precious asset of all - the public's trust - may increasingly be at risk $\left.{ }^{3}\right)$. 
protect the government's interest in providing its benefits to worthy enterprises, but also whether the new reforms promote or detract from clear communication with stakeholders - whether they cause 'brand confusion'.

This chapter proceeds in three parts. First, it introduces the two primary ways in which the law of nonprofit organizations attempts to regulate the boundary between the nonprofit and business sector: restricting nonprofits to certain less commercial purposes; and imposing the non-distribution constraint. Second, the chapter roots commercial activity by nonprofits in a long history of fee-for-service nonprofit organizations operating in similar ways to for-profit businesses, sometimes competing to provide the very same services. While these commercial nonprofits have existed for some time, industry observers agree that commercial nonprofits are growing and expanding the ways in which they are challenging the traditional boundary between the nonprofit and business sectors. Finally, the chapter introduces a series of new legal forms created to facilitate so-called 'social enterprises'. These new business forms are very varied, and largely disclaim access to the governmental benefits provided to nonprofits in order to avoid the governmental regulation that comes with such benefits. But, they are each more or less devoted to instituting some alternative regime to replace the 'branding' function of membership in the traditional nonprofit sector, and are therefore of concern to scholars of the nonprofit sector.

\section{WHAT DISTINGUISHES A NONPROFIT?}

As a practical matter, the law of nonprofits draws the boundary of the nonprofit sector based on two types of distinctions between sectors. First, the nonprofit sector has traditionally been confined to enterprises that pursue specified purposes. Second, the nonprofit sector has been confined to enterprises that are prevented from distributing their profits to private individuals - the so-called non-distribution constraint. Generally, when we describe an enterprise as 'nonprofit' (or 'not-for-profit') we are referencing the non-distribution constraint, the legal rule that makes a nonprofit a nonprofit. These two broad categories of legal rules (purpose requirements and the non-distribution constraint) apply differently to different classifications within the nonprofit sector, and they apply differently in different legal jurisdictions. But they are both implicated in our conceptions of the nonprofit sector, and it is worthwhile distinguishing between them when discussing proposed changes to the law.

First, with respect to purpose, it is worth pointing out that many jurisdictions in the US permit an enterprise to incorporate as a nonprofit (subject to the so-called 'non-distribution constraint') for any legal purposes, including a purely commercial one. These jurisdictions do not require that a nonprofit have any special social purpose. ${ }^{8}$ Purely commercial nonprofit corporations do not qualify for tax or other benefits (and are therefore not subject to any classification by the IRS), but they are legally permitted to exist, and do exist in relatively small numbers. The vast majority of

8 For example, the American Bar Association, 'Model Nonprofit Corporation Act' (3rd edn, 2008 ) $\$ 3.01$ (a) states: 'Every nonprofit corporation has the purpose of engaging in any lawful activity unless a more limited purpose is set forth in the articles of incorporation.' 


\section{Research handbook on not-for-profit law}

the nonprofit sector, however, consists of enterprises that are not only subject to the non-distribution constraint, but also required to pursue some special social purpose other than profit-making. In the US, tax benefits are provided to two broad types of special-purpose nonprofits: charities and other organizations. Charitable organizations are exempt from income taxes and their donors receive a deduction for donations to them, ${ }^{9}$ while non-charitable nonprofits may be exempt from tax on their income, but their donors generally are not permitted a deduction. ${ }^{10}$ Non-charitable nonprofits include many types of special purpose organizations, like political organizations, lobbying groups, social clubs, business leagues, and others. For the purposes of this chapter, I will limit my discussion of the nonprofit sector to the 'charitable' sector, both because most nonprofits in the US are charitable and because much of the scholarly and popular interest in the commercialization of the nonprofit sector applies to charities. Therefore, the most common special social purposes under discussion in this chapter are charitable purposes, which are derived from the English common law of charities.

As for the non-distribution constraint, it generally prevents nonprofits from distributing profits to private persons. That seems simple, but of course it is anything but. The non-distribution constraint is permeable, because nonprofits can pay excessive compensation to employees, or make improper payments to other providers of goods or services. They can similarly pay excessive returns on capital loaned to or invested in them. In addition, in the US at least, a nonprofit that pays any 'equity-type' return on capital has violated the rule, whether the return is excessive or not. ${ }^{11}$ The specific ways in which the non-distribution constraint might be breached are less important than the general observation that the non-distribution constraint is the primary mechanism by which the nonprofit sector is distinguished from the business sector.

The essence of the non-distribution constraint is an attempt to permit a wide range of stakeholders - contributors, volunteers, employees, managers, entrepreneurs, beneficiaries, neighbours, governments - to trust that other stakeholders are prevented from usurping any excess value created by the organization. ${ }^{12}$ They all renounce the appropriation of such excess value and agree that it should be used to advance the organization's social purpose. Therefore, the legal parameters of the non-distribution constraint may be perpetually contested, but its existence is widely believed to be at the heart of what makes the nonprofit sector possible.

9 Charitable organizations, in this sense, are those classified under IRC $\S 501$ (c)(3) (2005), the most common classification for nonprofit organizations in the US: see McKeever et al. (n 2) 3 (Table 1.1 there shows that of the 1,549,264 tax-exempt entities that report to the IRS, $1,179,739$ are classified under $\S 501$ (c)(3), which is over 76 per cent, and that excludes most churches and organizations with under $\$ 50,000$ in gross receipts, which are not required to file).

10 This is of course a substantial simplification. There are actually 36 classifications of tax-exempt organizations, each of which has slightly different legal treatment: see IRC $\$ 501(\mathrm{c})$ (2005).

I1 See Hopkins (n 3) $574 \S 20.6$.

12 See Lloyd Hitoshi Mayer, "The "Independent" Sector: Fee-for-Service Charity and the Limits of Autonomy' (2012) 65 Vanderbilt Law Review 51 (analysis of the ways the non-distribution constraint fosters 'autonomy' in nonprofit organizations). 
Each of these legal mechanisms for guarding the boundary between the nonprofit and business sectors is subject to contestation. It is an open question whether it is desirable for nonprofits to be permitted to engage in essentially commercial activities, so long as they are subject to the non-distribution constraint. Some question the usefulness of the non-distribution constraint. And one may answer each question differently depending on whether one is focused on the legal task of evaluating which organizations qualify for government benefits, or on the legal task of assisting stakeholders in evaluating which organizations are worthy of their heightened trust.

\section{COMMERCIAL NONPROFITS AND JOINT VENTURES}

In the United States, fee-for-service nonprofits have dominated the nonprofit sector for decades. ${ }^{13}$ This fee-for-service model is dominant largely because the largest institutions in the nonprofit sector are healthcare and education institutions that have relied primarily on fees (payments for services and tuition) for a long time. While some of these organizations receive substantial donative support, the overwhelming source of their revenue is fees paid by persons purchasing their services (students or patients) or their surrogates (parents or insurance, including government-provided insurance). These fee-supported nonprofits have been called 'commercial' nonprofits to distinguish them from 'donative' nonprofits, ${ }^{14}$ and their relationship to both government subsidies and the nonprofit 'brand' is distinct.

While fee-for-service nonprofits have always raised unique theoretical issues, commentators have focused more and more attention on commerciality because of a widely shared perception that it is growing in numerous different directions simultaneously. ${ }^{15}$ In many sectors, now, nonprofit providers compete with for-profit providers. In the healthcare context, for example, nonprofits exist alongside for-profit

13 See McKeever, Dietz, and Fyffe (n 2) 140-2 (Table 4.1 showing that 'sales receipts' accounted for 72 per cent of nonprofit revenue in 2014, up from 69 per cent in 2004).

14 Hansmann (n 6).

15 See, eg, Dennis R Young and Lester Salamon, 'Commercialization, Social Ventures, and For-Profit Competition' in Lester Salamon (ed), The State of Nonprofit America (Brookings 2002) 439-40 ('[i]n response to [a] combination of pressures and opportunities, nonprofit organizations are drawing far closer to the market economy than perhaps at any time in their history'). See also Peter Frumkin and Jonathan B Imbar (eds), In Search of the Nonprofit Sector (Transaction Publication 2004); Burton Weisbrod, 'Conclusion' in Burton Weisbrod (ed), To Profit or Not to Profit: The Commercial Transformation of the Nonprofit Sector (Cambridge University Press 1998) 287 ('[n]onprofit organizations' commercial activities are bringing revolutionary changes in traditional behavior, and in the process are blurring the distinction between nonprofits and private firms'). In 1998, the prologue to this collection of essays by economists stated that, '[n]ow [Weisbrod] and his colleagues have focused on a phenomenon always extant but of growing significance: the commercialization of the nonprofit sector. Almost all of what is known regarding this development is to be found in these pages': see Kenneth Arrow, 'Foreword' in Burton Weisbrod (ed), To Profit or Not to Profit: The Commercial Transformation of the Nonprofit Sector (Cambridge University Press 1998) ix. While no doubt an overstatement even in 1998 , the claim is certainly false now. 
entities providing services that are, in many instances, indistinguishable from their for-profit competitors. ${ }^{16}$

In the context of fee-for-service nonprofits, the question of how and where the legal boundary between the nonprofit and business sector should be drawn is problematic. Fee-for-service charities are capable of making significant profits, even without tax or other subsidies, and yet the income of nonprofit providers is exempt from corporate tax. ${ }^{17}$ Because of this, some commentators argue that commercial nonprofits should be required to do more to justify their charitable status than they currently do. ${ }^{18}$ Usually, the criticism of commercial nonprofits focuses on the fact that they fail to sufficiently take into account distributional concerns. In other words, they do not sufficiently serve the poor. For example, in the medical context, US critics of existing nonprofit law have argued that the purpose of 'promoting health' is an insufficient charitable purpose, and hospitals should provide more 'charity care', or otherwise serve the poor. ${ }^{19}$ In the educational context, US critics have argued that elite private universities (with large endowments) insufficiently serve students who are unable to afford them (or improperly shift too much cost to students), and so they should be forced to spend a larger proportion of their endowment reducing student cost. These criticisms are usually focused on the 'subsidies' or benefits that nonprofit providers receive, and so the question is simply: does the law require nonprofit providers to 'earn' their subsidies by serving the poor, or not?20 If not, perhaps the subsidies should be removed.

Sometimes the critique of commercial nonprofits does not focus on distributional concerns, but simply asserts that such operations are 'too commercial'. In fact, there is a free-standing but extremely ill-defined 'commerciality' doctrine, which the IRS has used to deny tax-exempt status to a whole number of firms whose operations are not sufficiently distinguishable from for-profit participants in a particular market. ${ }^{21}$ The claim about commerciality is not about the non-distribution constraint, and these commerciality-doctrine cases are not arguments that individuals are profiting from the operation of the organization. Those claims would be 'private inurement' or 'private benefit' claims. The claim here is a subcategory of the requirement that an organization be operated for charitable purposes, and the idea is that an organization with an overly "commercial hue' could not be so operated. ${ }^{22}$ But in these cases, most examples involve

16 See Young and Salamon (n 15).

17 To the degree to which such organizations receive no donations, the tax deductibility of donations is not an issue, although when they do receive donations it becomes one.

18 Underlying this debate is an empirical question about whether nonprofit service providers behave differently from for-profits. For a study finding that they do behave differently in ways that enhance the public good, see Jill R Horwitz, 'Does Nonprofit Ownership Matter?' (2007) 24 Yale Journal on Regulation 139.

19 See Evelyn Brody, 'The 21st Century Fight Over Who Sets the Terms of the Charity Property Tax Exemption' (2016) 77 Exempt Organization Tax Review 259.

20 See, eg, Miranda Perry Fleischer, 'Theorizing the Charitable Tax Subsidies: The Role of Distributive Justice' (2010) 87 Washington University Law Review 505.

21 See, eg, John D Colombo, 'Reforming Internal Revenue Code Provisions on Commercial Activity by Charities' (2007) 76 Fordham Law Review 667.

22 It is perhaps worth pointing out that prior to 1950 , the US adopted a 'destination of income' test, which recognized the charitable status of commercial enterprises that devoted all of 
industry sectors historically dominated by for-profit firms, in which nonprofits are seeking entry, and some of the argument is about competing with for-profit firms, or using methods too similar to for-profit firms that do similar business. ${ }^{23}$ However, the contours of this commerciality overlay to the charitable purposes tests are extremely hard to define. ${ }^{24}$ More fundamentally, there is no theoretical consensus on why nonprofits should be required to differentiate themselves from 'ordinary' businesses, as long as the non-distribution constraint is being enforced. ${ }^{25}$

Thus, without focusing on any new stretching of boundaries or new phenomenon in the law, it is apparent that the boundary between nonprofits and commercial activity is not clear, and nor is it clearly theorized. For the purposes of determining which organizations should receive government subsidies through the tax code, there is a sense that a line needs to be drawn that adequately directs subsidies to enterprises that accomplish (or at least seek to accomplish) 'special' social purposes, and some boundary is needed to distinguish these enterprises from 'ordinary' commercial operations. For the purposes of 'branding' however, it may well be that the nondistribution constraint is sufficient to communicate to stakeholders the 'specialness' of the firm in question. After all, the hotchpotch of factors that seem to play into a determination of commerciality do not seem especially useful for that purpose. But, if stakeholders are relying on the non-distribution constraint, then structures that permit the distribution of profits under certain circumstances might weaken the sector.

Issues related to the commerciality of nonprofits have been significantly complicated in the United States by an increase in the use of various combinations of business forms in the nonprofit sector in the last several decades. Traditionally in the US, determinations about tax exemption have been made on an entity-by-entity basis, so that the activities of a separately incorporated for-profit subsidiary of a nonprofit parent would not be used to determine if the parent qualifies for tax-exempt status. Likewise, a subsidiary's commercial activities are not imputed to its parent, as long as the subsidiary is housed in a separate corporation. However, if an organization engages in those activities 'directly' or through a joint venture (including a partnership or business form taxed as a partnership), the business activities would be imputed to the parent.

their income to charity (so-called 'feeders'), but in 1950 Congress changed the law to deny tax-exempt status to feeder organizations. Recently, the status of feeder organizations was raised in Australia. See, generally, Kerry O'Halloran, The Profits of Charity (OUP 2012) 493-4.

23 See, eg, Hopkins (n 3) 134 \& 4.11(a) ('[a]n activity is a commercial one if it has a direct counterpart in, or is conducted in the same or similar manner as in, the realm of for-profit organizations ... having stated the essence of the doctrine, it must also be said that it is unevenly applied').

24 For example, a leading scholar of the commerciality doctrine stated that '[i]n short, the Treasury Regulations, IRS interpretations and litigating positions, and court cases all seem to be inconsistent in judging when commercial activity should result in loss of exempt status': Colombo (n 21) 678.

25 See, eg, Hopkins (n 3) $135 \$ 4.11$ (b) ('[i]n short, the assumptions underlying the rationale for the commerciality doctrine are severely flawed. Some of the assumptions are not in accordance with law requirements and/or common sense. A few of these assumptions are outmoded. All of this is exacerbated by the IRS's overly aggressive application of the commerciality doctrine'). 
If a partnership engages in commercial activities and makes a profit, that profit is taxable to the degree to which it is attributable to any for-profit partner, but may be exempt to the degree to which it is attributable to a tax-exempt partner. ${ }^{26}$ This state of affairs has resulted in a number of rulings about joint ventures (and other similar arrangements) between tax-exempt nonprofits and taxable businesses. The outcome of these rulings (at least to date) has been relatively permissive towards commercial joint ventures that advance the tax-exempt purposes of the nonprofit parent, with very little free-standing commerciality discussion. In effect, so long as the joint venture is controlled by the charitable parent, and advances the parent's charitable purpose, then the venture's commerciality does not impact the parent's qualification for tax-exempt status. Neither does the fact that it distributes profits to any commercial co-venturers.

Joint ventures are especially useful to create 'hybrid' business entities that can address some of the criticisms that social enterprise reformers make of the nonprofit sector. For example, one of the most fundamental critiques of the nonprofit form is that the non-distribution constraint prevents nonprofits from raising capital from 'equity' investors. Because equity is often preferable to debt when a venture is risky, and because nonprofits often have difficulty accessing debt financing, this impediment can be significant. ${ }^{27}$ Nonprofits that structure a social enterprise as a joint venture can potentially raise donated (tax-deductible) capital through their nonprofit partner, and commercial debt or equity capital through their for-profit partner(s), thus delivering a true 'hybrid' enterprise structure. The activities of the joint venture are attributed to the nonprofit, so there is still a burden to show that those activities are in furtherance of the nonprofit's tax-exempt purposes if the activities are substantial. ${ }^{28}$ But many social enterprises could presumably meet this test. ${ }^{29}$

In determining whether joint ventures negatively impact the tax exemption of their nonprofit partners, the IRS has focused on control. If the tax-exempt partner controls the joint venture, and if the joint venture otherwise advances the nonprofit's tax-exempt purpose, then there is no problem. If the joint venture is controlled by for-profit partners, then no matter how it behaves, the IRS does not consider it to be advancing the tax-exempt purpose of the nonprofit. ${ }^{30}$ In that case, if the joint venture's activities are substantial in relation to those of the nonprofit, then the nonprofit would no longer

26 The question of taxability of this income would be evaluated under the rules on the unrelated business income tax (UBIT): see IRC $\$ 512$.

27 In fact, it is this restriction on business sources of capital that justifies tax benefits in the eyes of some: see, eg, Mark P Gergen, 'The Case for a Charitable Contributions Deduction' (1988) 74 Virginia Law Review 1393; Henry Hansmann, 'The Rationale for Exempting Nonprofit Organizations from the Corporate Income Tax' (1981) 91 Yale Law Journal 54.

28 There also may be other legal issues, most importantly private inurement or private benefit issues. For a discussion of private inurement and private benefit in a social enterprise joint venture or hybrid situation, see Benjamin M Leff, 'Preventing Private Inurement in Tranched Social Enterprises' (2015) 45 Seton Hall Law Review 1.

29 See generally Michael I Sanders, Joint Ventures Involving Tax Exempt Organizations (4th edn, Wiley 2013).

30 The leading case on this issue is still St David's Health Care System v United States 349 F 3 d 232 (5th Cir, 2003). 
qualify for tax-exempt status. ${ }^{31}$ Relying so heavily on control presumably reflects the theory that the key to a joint venture being protected from abuse by its for-profit partners is the supervision of the nonprofit directors. So long as they are subject to the non-distribution constraint, then in effect they can be trusted to oversee the joint venture such that it will not divert resources from the nonprofit mission, even as it pays an investment return to its for-profit investors.

This approach is still very much being developed, and is subject to considerable contestation. Since profits are taxed to the degree that they are attributable to the non-charitable partner(s), thus potentially neutralizing the tax exemption question, joint ventures raise the issue of how important the 'branding' function of nonprofit law is. When a charity operates a commercial subsidiary, along with profit-making partners, to advance a substantial part of its charitable purpose, do stakeholders have sufficient information to know how much to 'trust' that enterprise?

\section{4. 'SOCIAL ENTERPRISES' AND THE CRITIQUE OF THE NON-DISTRIBUTION CONSTRAINT}

As discussed above, much of the expansion of commercialism in the nonprofit sector is caused by innovation among nonprofits pushing legal boundaries. The law in the US in this area is arguably in a state of flux. It is permissible for nonprofits to use hybrid forms (like joint ventures) to combine traditional charities with for-profit businesses, thereby opening up the possibility of combining capital from charitable sources with capital from profit-seeking investors. But this development of joint ventures comes from squarely within the nonprofit sector, seeking a solution to the problem of nonprofits accessing capital or other resources from the business sector. Some perceive these innovations as alarming, while others believe that joint ventures do not go far enough. These thinkers seek to radically re-envision the relationship between business entities and socially beneficial purposes through so-called 'social enterprises' ${ }^{32}$

The 'social enterprise' movement has advocated for new business forms to populate what is sometimes described as a 'fourth sector'. ${ }^{33}$ This social enterprise movement is both a critique of traditional charities (which are perceived as insufficiently entrepreneurial and overly reliant on donations or government support), and of traditional business enterprises (which are perceived as overly concerned with profit maximization for shareholders). A number of jurisdictions have been experimenting with new legal forms for social enterprises, which stretch the boundary between nonprofits and businesses even further. Some of these business forms retain the non-distribution

31 If the activities of the joint venture are insubstantial in relation to the activities of the tax-exempt partner, then the joint venture is an 'ancillary joint venture,' and 'the question remains whether control is needed in the ancillary joint venture setting': Hopkins (n 3) 1236 $\$ 31.4$.

32 See, generally, Robert A Katz and Antony Page, 'The Role of Social Enterprise' (2010) 35 Vermont Law Review 59.

33 See Thomas Kelley, 'Law and Choice of Entity on the Social Enterprise Frontier' (2009) 84 Tulane Law Review 337, 340. 
constraint, some modify it, and some do away with it completely. If seen simply as a reform of the business sector, these new social enterprise business forms would have few implications for nonprofit law. But because they use the law to create a social enterprise brand - one that has the potential to compete or be confused with the nonprofit brand - they are more than just a reform of business law, and are worthy of study in a volume about the nonprofit sector.

The 'social enterprise' movement has challenged both (i) the fundamental idea that socially beneficial activities should be confined to a list of traditional purposes and (ii) the fundamental idea that the non-distribution constraint is necessary for socialpurpose activities. Some social enterprise supporters argue that social good can be pursued in a wide range of activities that seem more commercial than charitable (such as providing goods or services to low income people, or providing regular goods while committing to directing some profits to a social goal). Some also argue that the non-distribution constraint is unnecessary and prevents some worthwhile organizations devoted to social purposes from operating effectively. ${ }^{34}$ Both types generally argue that the boundary between businesses and nonprofits is too sharply drawn. Some may use language that suggests that the boundary should be done away with altogether, but their proposed reforms generally are much more modest and seek to facilitate the pursuit of social purposes by for-profit firms or facilitate socially beneficial commercial activity by nonprofits. ${ }^{35}$ Most social enterprise advocates are not legal scholars at all, and many of their proposals are directed at changing the culture of business, charity, philanthropy, nonprofit management, for-profit management, and other things. But there is a general call for changes to the law to facilitate social enterprises, and these social enterprise legal reformers have lobbied legislatures to create a multitude of new legal forms that purport to solve a variety of problems associated with this too-rigid boundary.

This social enterprise legal movement has sought to develop new legal forms to house such social enterprises in a single 'off-the-rack' entity, rather than in traditional businesses or charities, or in specialized joint venture arrangements. These new social enterprise legal forms are, on the one hand, more radical than joint ventures because they attempt to create something new to address the problems raised by mixing social and business interests. On the other hand, because they largely disclaim any attempt to qualify as tax exempt or be considered charities, they disclaim the governmental benefits available to the nonprofit sector, and only implicate what we have been calling branding concerns. These new business forms include Low Income Limited Liability Companies, Benefit Corporations, Social Purpose Corporations, and Flexible Purpose Corporations in the US, and Community Interest Companies in the UK. ${ }^{36}$

34 Some of the strongest advocates for social enterprises that serve the poor strongly disagree with those who wish to remove the non-distribution constraint. For example, Muhammad Yunus insists that 'social businesses' should not distribute profits to investors but should reinvest proceeds to serve their mission: Muhammad Yunus, Building Social Business: The New Kind of Capitalism that Serves Humanity's Most Pressing Needs (PublicAffairs 2010).

35 See generally Anup Malani and Eric A Posner, 'The Case for For-Profit Charities' (2007) 93 Virginia Law Review 2017, 2065; M Todd Henderson and Anup Malani, 'Corporate Philanthropy and the Market for Altruism' (2009) 109 Columbia Law Review 571.

36 See Robert T Esposito, 'The Social Enterprise Revolution in Corporate Law: A Primer on Emerging Corporate Entities in Europe and the United States and the Case for the Benefit 
The social enterprise legal reformers have proposed these new business forms with two goals in mind. First, social enterprise legal reformers critique what they describe as the overly restrictive nature of both charity law and business law. In response to these restrictions, they call for legal forms that are less restrictive; an impulse I call 'de-regulatory'.37 From the business-law side, they argue that company law requires for-profit businesses to maximize shareholder profit, and that profit-maximization prevents social enterprises from seeking to advance their social missions. Therefore, they seek legal reforms that permit social enterprises to pursue social mission over profit. Many legal scholars argue that this critique is largely unfounded, at least in the US, since the so-called 'business judgment rule' permits the directors of a business much discretion, and most states explicitly permit directors to consider factors other than profit maximization in exercising their judgment. ${ }^{38}$ In any case, these de-regulatory goals are met easily, since profit-maximization rules in US corporate law can generally be overruled by clear communications to shareholders.

From the nonprofit and charity-law side, these reformers sometimes argue that traditional charitable purposes are too narrow, and they complain that the nondistribution constraint prevents socially beneficial investment by providers of capital. ${ }^{39}$ Thus, they seek a business form that permits entrepreneurs to attract investment from capital markets that demand a share of the profits of the firm. These social enterprise legal reformers seek to 'deregulate' charity law so their enterprises can pursue their socially beneficial purposes as effectively as possible, no matter how much of their profits they pay to their investors.

But, these legal reformers rarely propose purely de-regulatory legal reforms. Instead, they appear to be acutely conscious of the need to distinguish enterprises that genuinely pursue social goals from those that merely seek to maximize profits. That is, it seems clear that entities that seek to advance the social good want to be able to make credible commitments about the social value of their work to their various constituencies, and

Corporation' (2013) 4 William and Mary Business Law Review 639, 671 (discussing US entities and contrasting them with those of the UK and continental Europe). This chapter is focused on the social enterprise movement in the US, with some discussion of the UK. The movement in continental Europe is different enough that a separate treatment would be warranted: see generally Rory Ridley-Duff and Mike Bull, Understanding Social Enterprise: Theory and Practice (2nd edn, Sage 2015) 167 (distinguishing between US-style 'social purpose enterprises' and EU-style 'socialized enterprises').

37 For a discussion of the 'deregulatory' and 'regulatory' impulses of the social enterprise movement, see Leff, 'Preventing Private Inurement' (n 28) 4-7.

38 See, eg, Einer Elhauge, 'Sacrificing Corporate Profits in the Public Interest' (2005) 80 New York University Law Review 733,763 . But social enterprise advocates generally point to eBay Domestic Holdings Inc v Newmark, 16 A 3d 1 (Del Ch 2010) (holding that the implementation of an anti-takeover measure designed to protect a private company's corporate culture breached the directors' fiduciary duty to maximize shareholder value).

39 They also sometimes argue that restrictions on compensation prevent social enterprises from attracting talent, but they generally misunderstand the actual state of law, in the US at least, with respect to nonprofit compensation: see, eg, Benjamin M Leff, 'The Case against For-Profit Charity' (2012) 42 Seton Hall Law Review 819, 839-44. 
they seek support from the law to enable them to make such commitments. ${ }^{40}$ In other words, they want the law to provide them with a credible 'brand' to communicate to stakeholders their commitment to the social good and to distinguish them from firms that are not so committed. ${ }^{41}$ I call this element of their proposals 'regulatory', since it attempts to replace some regulation of social enterprises, once the traditional boundary between charities and commercial businesses is removed. The central concern of most scholarly critics of these new legal forms is that they do too little to provide an actually effective mechanism for distinguishing social enterprises from regular ones; and so there is the risk that the social enterprise label will fail to become an effective brand, or, worse, will mislead constituencies into believing that enterprises adopting the new forms are something that they are not. ${ }^{42}$ Of course, there is also the risk that social enterprises will improperly associate themselves with the brand of nonprofits, thereby weakening the nonprofit brand. 43

The prehistory of modern social enterprise legal forms is probably the cooperative movement of the nineteenth century. Critiques of the excesses of profit-maximizing capitalists produced workers' collectives and consumer coops, like those famously formed by workers in Rochdale, England. The Rochdale model required workers or consumers to collectively supply capital to their ventures, and initially paid a limited five per cent return on such capital, although later moved away from paying dividends measured by investment amount. ${ }^{44}$ These enterprises were distinguished from other businesses by their democratic character: ultimate decisions were made by patrons or workers, not by shareowners. It is the expansion of this cooperative movement in continental Europe that initially laid claim to the term social enterprise, and it gave rise to a wave of social enterprise lawmaking, as country after country in Europe adopted new legal forms to permit the spread of democratically controlled businesses for a number of different purposes. ${ }^{45}$

If the history of cooperatives represents a source of the social enterprise movement that emphasizes democratic decision-making as the distinguishing characteristic from ordinary businesses, philanthropist/owners also experimented with mechanisms to

40 They fear that their efforts will be perceived as no more than corporate puffery, often called 'greenwashing' in the environmental context.

41 See, eg, Dana Brakman Reiser, 'Theorizing Forms for Social Enterprise' (2013) 62 Emory Law Journal 681, 684 ('for the adoption of a specialized legal form to indicate that an entity actually is different, it must impose a new and unambiguous baseline standard and provide for its reliable enforcement. Only by doing so can a specialized legal form reach the ultimate goal of social entrepreneurs who seek them: to become a brand.').

42 See, eg, Lloyd Hitoshi Mayer and Joseph R Ganahl, 'Taxing Social Enterprise' (2014) 66 Stanford Law Review. 387, 397 ('Many commentators opposed the creation of L3Cs [because they believed that $\mathrm{L} 3 \mathrm{Cs}$ ] simply represented a desire to trade on the cachet of government imprimatur").

43 Richard Steinberg and Bradford H Gray, "The Role of Nonprofit Enterprise" in 1993: Hansmann Revisited' (1993) 22 Nomprofit and Voluntary Sector Quarterly 297, 303 ('[t]hese for-profits in disguise as nonprofits would degrade the quality of the "nonprofit seal of approval"').

${ }_{44}$ See Steve Leikein, The Practical Utopians: American Workers and the Cooperative Movement in the Gilded Age (Wayne State University Press 2005) 3-5.

45 See generally Ridley-Duff and Bull (n 36). 
engage in what they may well have called social enterprise, had the term yet been introduced. For example, Nathan Mayer Rothschild created the so-called 'Four-Percent Industrial Dwelling Company', which built worker housing in London, limiting the return on capital to only four per cent. There was no special legal form, and the purpose - providing housing to workers - was something that plenty of regular profit-oriented businesses did. But Rothschild put the limitation on return of capital right in the name of the company, in order to communicate that there was an aspect of philanthropy in the enterprise. It is this strain of social enterprise that has been developing in the US, and to a slightly lesser degree in the UK, and it has spurred the creation of very different new legal forms.

These new legal forms were created for a variety of purposes, but it is useful to identify the way each one deals with the legal boundary between the nonprofit and business sectors. ${ }^{46}$ In other words, to what extent do these new business forms create a regulatory regime that has the potential to enable stakeholders to distinguish between social enterprises and 'ordinary' businesses, assuming that such differentiation is one of the goals of the new forms? Specifically:

(i) these new legal forms deal differently with the 'purposes' requirements that restrict charitable organizations under current law;

(ii) these new forms have different requirements with respect to the non-distribution constraint; and

(iii) they deal with legal enforcement issues differently.

Some are more innovative than others, and with more innovation, of course, comes more risk of harm.

Before any new legal forms were introduced in the US, the UK introduced the Community Interest Company (CIC) in 2004. A CIC has wide latitude in the purposes it pursues, although its activities must be carried on "for the benefit of the community' ${ }^{47}$ With respect to the non-distribution constraint, all CICs are subject to an 'asset lock'. The asset lock prevents CICs from selling their assets at below-market rates, and from distributing their assets to owners or others on dissolution of the company. However, they are permitted, if they choose, to distribute operational profits to investors or owners, subject to a 'dividend cap'. CICs may also choose to operate 'by guarantee', which means that they will not distribute any profits to shareholders. Thus, the social-enterprise legal form first adopted in the UK provides an expansion of purpose to include any social purpose, and a relaxation, but not complete removal, of the non-distribution constraint. Most importantly, the UK created a new regulatory body to police CICs and enforce compliance with the law. This regulator also provides a means to continue to refine definitional issues, like what social purposes will be permitted to CICs, and so permits an evolving approach to social enterprise law.

In the US, the first new social enterprise legal form to be enacted was the Low Income Limited Liability Company (L3C), first adopted by the state of Vermont in

46 For a good comparative analysis of the new social enterprise legal forms, see, eg, Reiser, 'Theorizing Forms for Social Enterprise' (n 41).

47 The Community Interest Company Regulations 2005, SI 2005/1788, reg 4. 
2008. Unilike the CIC, L3C statutes purposely mimic the 'purposes' requirement found in charity law, requiring that an L3C operate to 'significantly further the accomplishment of one or more charitable or educational purposes', and '[n]o significant purpose of the company is the production of income or the appreciation of property'. ${ }^{48}$ Also unlike the CIC, an L3C has no explicit restrictions on its ability to distribute profits to its members. Supporters claimed that the explicit prioritizing of social purpose over profits would signal to members that profits were likely to be low, but there is no legal requirement that profits be limited. Finally, because an $\mathrm{L} 3 \mathrm{C}$ is not a tax-exempt entity, it avoids all federal regulation of nonprofits. Some have argued that state regulators would continue to have jurisdiction over $\mathrm{L} 3 \mathrm{Cs}$, at least sometimes, ${ }^{49}$ but state regulation of nonprofits has been criticized as being inconsistent and lax. Thus, as a social enterprise business form, the $\mathrm{L} 3 \mathrm{C}$ seems to provide little or no enforceable assurance to its stakeholders that it is different in any meaningful way from an ordinary business.

The lack of legal restrictions presumably comes from the L3C's history. Its initial express purpose was to facilitate investments not by individuals, but by so-called 'private foundations' - a subcategory of charity in the US subject to a stricter regulatory regime than public charities. The $\mathrm{L} 3 \mathrm{C}$ mimicked the regulatory language that authorized so-called 'program related investments', in an attempt to persuade private foundations that investing in L3Cs would qualify as program related. When the IRS declined to issue guidance supporting the idea that an investment in an $\mathrm{L3C}$ automatically qualified as a program-related investment, most commentators concluded that the form did not succeed in its primary purpose, or even that it was 'inherently misleading'. ${ }^{50}$

Thus, the L3C was initially intended to facilitate a structure like the joint venture structure described above, in which sophisticated charitable entities were deeply involved in how the social enterprise operated. Because of that, it was subject to the same basic logic that the IRS has taken with respect to joint ventures - that as long as the charitable directors are in charge of ensuring that the new venture advances the charity's charitable purpose, and as long as they control the terms under which any profits are distributed, there is no presumptive violation of the charity's qualifications.

The L3C appears to have moved beyond its beginnings as a vehicle for investments by private foundations and is being pitched as a useful legal form for free-standing social enterprises with for-profit investors. ${ }^{51}$ Currently eight states (and two Native

\footnotetext{
48. 11 VSA \$ $4162(2015)$.

49 See, eg, Dana Brakman Reiser, 'Regulating Social Enterprise' (2014) 14 University of California Davis Business Law Journal 231, 240-5. Notably, the Illinois L3C statute, unlike others, defines the directors of an L3C as charitable trustees under the state's Charitable Trust Act, triggering obligations to and oversight of the Illinois Attorney General: at 235.

50 Daniel S Kleinberger, 'A Myth Deconstructed: The Emperor's New Clothes on the Low-Income Limited Liability Company' (2010) 35 Delaware Journal of Corporate Law 879, 881.

51 See John Tyler, "Negating the Legal Problem of Having "Two Masters": A Framework for L3C Fiduciary Duties and Accountability' (2010) 35 Vermont Law Review 117, 125 (arguing that $\mathrm{L} 3 \mathrm{Cs}$ are not only meant to attract investment from charitable foundations).
} 
American Tribes) authorize L3Cs, and an estimated 1,560 have been created. ${ }^{52}$ As a free-standing social enterprise vehicle, the L3C appears to be an attempted 'brand' with no institutional mechanism to protect the interests of stakeholders who want to preserve the social mission. Even though it technically does not broaden the authorized purposes beyond those that apply to charities, the lack of a regulator may permit de facto broader purposes. The $\mathrm{L} 3 \mathrm{C}$ has no restriction on distributing its profits to owners and, because it has no new mechanism to enforce the primacy of its social purpose, its commitment to such purposes may prove weak.

Starting in 2012, state legislatures began to enact statutes creating a new social enterprise business form, the Benefit Corporation. ${ }^{53}$ Benefit Corporation statutes were enacted in response to lobbying by the founders of a nonprofit organization called B Lab, which had created a system of certifying the social benefit of social enterprises, an attempt to use private means to create a brand for social enterprises. Unlike the L3C, the Benefit Corporation is not designed to attract investment from entities that are already committed to charitable missions, but is instead designed to attract investors who want to support social enterprises directly. Because of that, the form does away with the concept of prioritizing some specific social benefit purpose over shareholder returns, and instead requires only that an enterprise be operated for 'a general public benefit'. What exactly a general public benefit is remains largely undefined, except that the statutes generally require that it be 'comprehensive' and that it be 'measured against a third party standard'.

This concept of a third party standard is central to the Benefit Corporation, and it reflects the law's connection to B Lab. This third-party standard provides almost limitless variation in what could constitute a public benefit, but requires a Benefit Corporation to find a reputable organization (like B Lab) to create a standard against which the Corporation can measure its progress, although it does not require the Corporation to have the third party measure its conformance to the standard. Thus, the Benefit Corporation constitutes a radical rethinking of how the law should recognize organizations that serve the public good, completely discarding the historical list of charitable purposes.

As for the non-distribution constraint, the Benefit Corporation statutes permit any amount of profit distribution. Because Benefit Corporation laws do not create nonprofit organizations, Benefit Corporations do not qualify for tax exemption. That means that they are unregulated by the IRS. While no new regulator is created to enforce their compliance with their social purposes, the Benefit Corporation statutes generally substitute attempts at transparency and direct accountability for the existence of any regulator. With thirty-one different Benefit Corporation statutes, there is now a significant amount of variation about what exactly the form requires, especially with regard to mechanisms for stakeholders to enforce pursuit of the social mission.

52 See 'L3C Tally' (interSector Partners, L3C, 15 August 2017) <http://www.intersector $13 c . c o m / 13 c>$ accessed 27 September 2017. Prior to 1 January 2014, there were nine states that authorised L3Cs, but North Carolina repealed its L.3C law.

53 As of September 2017, thirty-two states and the District of Columbia have passed Benefit Corporation statutes: 'State by State Status of Legislation' (Benefit Corporation, 2017) <http:// www.benefitcorp.net/policymakers/state-by-state-status> accessed 27 September 2017. 
Generally, the statutes require some form of reporting to stakeholders about progress toward social goals, but very little in the way of other tools for stakeholders to enforce specific actions towards such goals.

Many of the statutes provide for some kind of limited cause of action by some specific stakeholders to enforce pursuit of social goals, but the limitations generally make the cause of action unlikely to ever bring much relief. Thus, while the Benefit Corporation statutes discard both the traditional purposes requirements and the nondistribution constraint, they do attempt to create new mechanisms to permit the corporation to make credible commitments to stakeholders about the entity's specialness, even if those new mechanisms to date seem hard for stakeholders to interpret or understand.

Not completely satisfied with the possibilities provided by the Benefit Corporation form, California created the 'Flexible Purpose Corporation' in 2011 (on the same day it enacted its Benefit Corporation statute), and Washington State followed in 2012 by enacting the 'Social Purpose Corporation' (SPC). ${ }^{54}$ Subsequently, California changed the name of its Flexible Purpose Corporations to Social Purpose Corporations. ${ }^{55}$ SPCs share some aspects of the Benefit Corporation, such as the requirement that they make publicly available reports about the activities that support their social purposes, but they are not required to measure their progress against a third-party standard. The SPC permits social enterprises to identify their own social purposes, purposes that can be less comprehensive than those required of Benefit Corporations. These social purposes . can be anything 'intended to promote positive ... effects of, or minimize adverse ... effects of, the corporation upon any or all of [a list of stakeholders that includes] the local, state, national, or world community'. ${ }^{56}$

It is surely an understatement to say that this definition of the purposes of a SPC is broad. Critics have complained that this "combination of unchecked directorial power and lack of standardized and independent reporting requirements ... have historically been poor bedfellows for social and environmental progress'. ${ }^{57}$ In other words, SPCs suffer from the same problems as Benefit Corporations, but possibly in a higher degree - they do not provide any clear signal to stakeholders that they are worthy of a higher level of trust or regard than any other business.

It is possible to make a few observations about the new social enterprise legal forms in the US. First, to the degree to which they do not implicate tax subsidies or other governmental benefits, the burden on the law is lighter than the burden of 'nonprofit law. ${ }^{58}$ On that score, there is no need to criticize them for being less effective than nonprofit law at identifying worthy enterprises. If they were purely de-regulatory, and

54 See, eg, Esposito (n 36) 692-4; Reiser, 'Regulating Social Enterprise' (n 49).

55 Currently, the only state other than California and Washington to have a Social Purpose Corporation statute is Florida.

56 RCW 23B.25.020 (2016).

57 Robert T Esposito, 'The Social Enterprise Revolution in Corporate Law: A Primer on Hybrid Corporate Entities in Europe and the United States and the Case for the Benefit Corporation' (2013) 4 William and Mary Business Law Review 639, 692.

58 For a thorough discussion of the arguments for extending tax benefits to social enterprises, that concludes that such extension is not warranted, see Lloyd Hitoshi Mayer and Joseph R Ganahl, 'Taxing Social Enterprise' (2014) 66 Stanford Law Review 387. 
only had the effect of permitting for-profit businesses to relax the requirement to maximize shareholder wealth, they would be relatively uncontroversial. However, they are not purely de-regulatory. Rather, they are designed to permit stakeholders to differentiate social enterprises from ordinary businesses. Supporters believe that stakeholders will treat social enterprises preferentially, either by investing in them, buying their products or services, preferring to work for them, appreciating them as neighbours, or other things. For social enterprises to succeed at this goal, they must create a recognizable brand, and that brand must enable them to make credible commitments to their stakeholders.

The second observation is that the law has a role in enabling social enterprises to make such commitments. In nonprofit law, that role is fulfilled by a purposes requirement, the non-distribution constraint, and a regulatory body to enforce the rules. If social enterprise laws are to do away with any or all of these tools, they must substitute something else. That is why these new laws are interesting. In the UK, the CIC form does not completely do away with the non-distribution constraint, but permits distribution of profits up to a restricted amount. But even more importantly, the UK legislation creates a new regulatory body to define and police a new evolving set of permissible purposes. In the US, where no new regulatory agency is created, and where the IRS is the most active regulator of the nonprofit sector, the fact that the new social enterprise legal forms avoid IRS regulation opens a void.

That void is filled by L3Cs in the same way that other joint ventures and hybrid structures are regulated: to the degree to which there is a tax-exempt partner, that partner must control the joint venture if its activities are substantial with respect to the nonprofit. However, if there is no tax-exempt partner, there is no regulation. In the case of Benefit Corporations, a wide variety of mechanisms are provided to substitute for government oversight. Benefit Corporations have more robust reporting requirements than other for-profit businesses; they must evaluate themselves against a third-party standard; they may have a special director who has individual responsibility to monitor social benefit; and they may have some very limited opportunity for stakeholders to bring a suit if they depart completely from their social purposes.

These mechanisms are exciting because they are new, but there is very little evidence that they will prove as effective as the non-distribution constraint as a commitment device for social enterprises. ${ }^{59}$ For many social entrepreneurs, the question that needs answering is whether the social enterprise brand will be effective at drawing stakeholders who value those things that social enterprises offer. But that is not the right question for legal scholars. For legal scholars, the right question is whether the branding of social enterprises communicates something important about them, or whether it operates as a kind of fraud, confusing stakeholders and providing them with something that is not real. Even more importantly, if this social enterprise brand draws

59 See Dana Brakman Reisèr, 'Benefit Corporations - A Sustainable Form of Organization?' (2011) 46 Wake Forest Law Review 591, 592-3 ("like the other hybrid forms simultaneously under development, the benefit corporation lacks robust mechanisms to enforce dual mission, which will ultimately undermine its ability to ... create a strong brand for social enterprise as sustainable organizations'). 
on the 'nonprofit seal of approval' 60 to create brand confusion with nonprofit enterprises, then it could negatively affect the value created by the non-distribution constraint to the detriment of the nonprofit sector.

\section{CONCLUSION}

At its heart, the central question about the boundary between the nonprofit and business sectors is, surely, whether there is a justification for a legal boundary at all. As it stands today, the primary purposes for the legal boundary are twofold - first, to identify those enterprises worthy of government-provided benefits like tax exemption, and second, to create a brand that enables stakeholders to identify enterprises worthy of their heightened trust, labour, capital, goodwill, patronage, or other things. Extensions of nonprofit enterprises into more and more commercial activities - whether within traditional charities, using hybrid structures, or using new social enterprise business forms - stretches and muddles the boundary, to the degree to which it was ever clear. Reforms to nonprofit law implicate both purposes: benefit-worthiness as well as brand recognition. New social enterprise business models, to the degree to which they disclaim tax and other government benefits, implicate only the branding issue, but by avoiding nonprofit law, they demand other legal solutions.

The important question for legal scholars, then, is whether one type of boundaryshifting legal reform is more 'dangerous' than another. On the one hand, hybrid models and expansions of the permissible activities of tax-exempt nonprofits are more dangerous because they implicate governmental subsidies, and because they directly affect the brand of the nonprofit or charitable sector itself. On the other hand, new social enterprise business forms, to the degree to which they create brand confusion or call into question the usefulness of the nonprofit sector at all, may be more dangerous in the long run. At their heart, these are empirical questions. In any case, there is no sign that innovation - including legal innovation - is likely to stop, and that is a good thing. Only innovation around the boundary will lead to a more clearly theorized and justified legal regime that permits both the business and nonprofit sectors to do a better job of advancing the social good.

60 Steinberg and Gray (n 43) 303. 